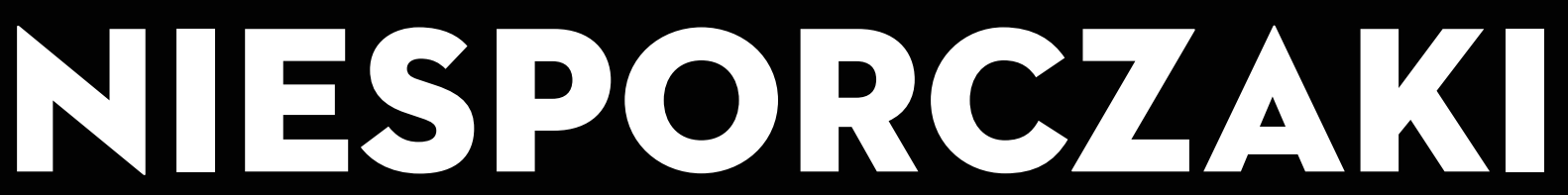

\title{
CZYLI SUPERBOHATEROWIE I ŚPIĄCE KRÓLEWNY
}

O niesporczakach mówi się bardzo często jako o zwierzętach niezniszczalnych, którym niestraszne są ani bardzo wysokie czy ekstremalnie niskie temperatury, ani długotrwałe susze, ani nawet ekspozycja na promieniowanie kosmiczne. Co kryje się za tą niezwykłą odpornością i czy na pewno nic nie jest w stanie im zaszkodzić? 


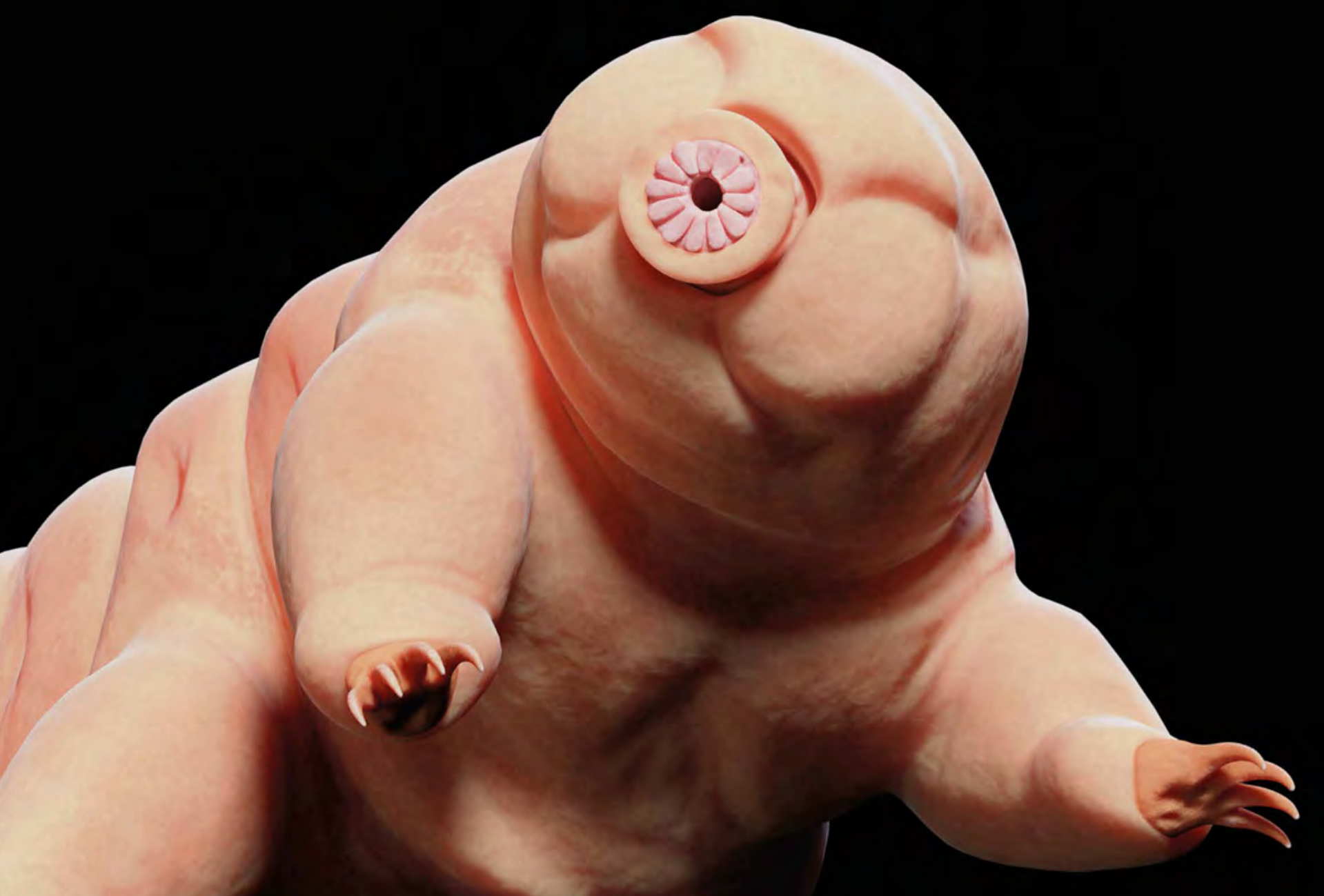

4)

m 


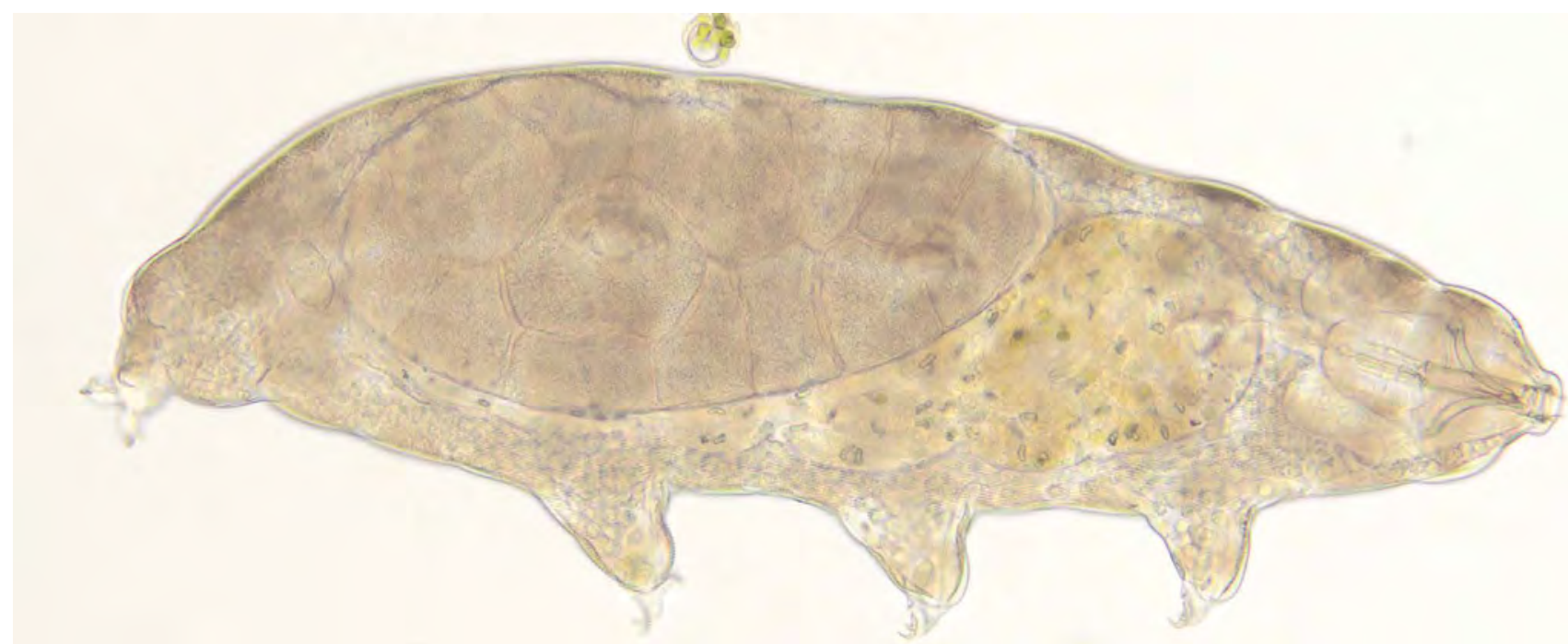

Samica Paramacrobiotus experimentalis tuż przed złożeniem jaj / fot. dr hab. Izabela Poprawa, prof. UŚ

- Niesporczaki nazywane są pieszczotliwie wodnymi niedźwiadkami, co znajduje zresztą odzwierciedlenie w ich angielskiej nazwie - water bears. To określenie wzięło się prawdopodobnie z pokroju ich ciała i sposobu poruszania się. Gdy się przemieszczają, są dosyć nieporadne i budzą jakiś szczególny rodzaj sympatii - mówi dr hab. Izabela Poprawa, prof. UŚ z Wydziału Nauk Przyrodniczych Uniwersytetu Śląskiego, która od lat bada te niezwykłe bezkręgowce.

Niesporczaki są przedmiotem wielu naukowych dociekań. Budowa ich ciała i niezwykła zdolność przetrwania w najtrudniejszych, ekstremalnych warunkach budzą ogromne zainteresowanie.

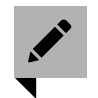
tekst: dr Małgorzata Kłoskowicz

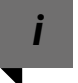

dr hab. Izabela Poprawa, prof. UŚ

Instytut Biologii, Biotechnologii i Ochrony Środowiska Wydział Nauk Przyrodniczych

Uniwersytet Śląski

izabela.poprawa@us.edu.pl

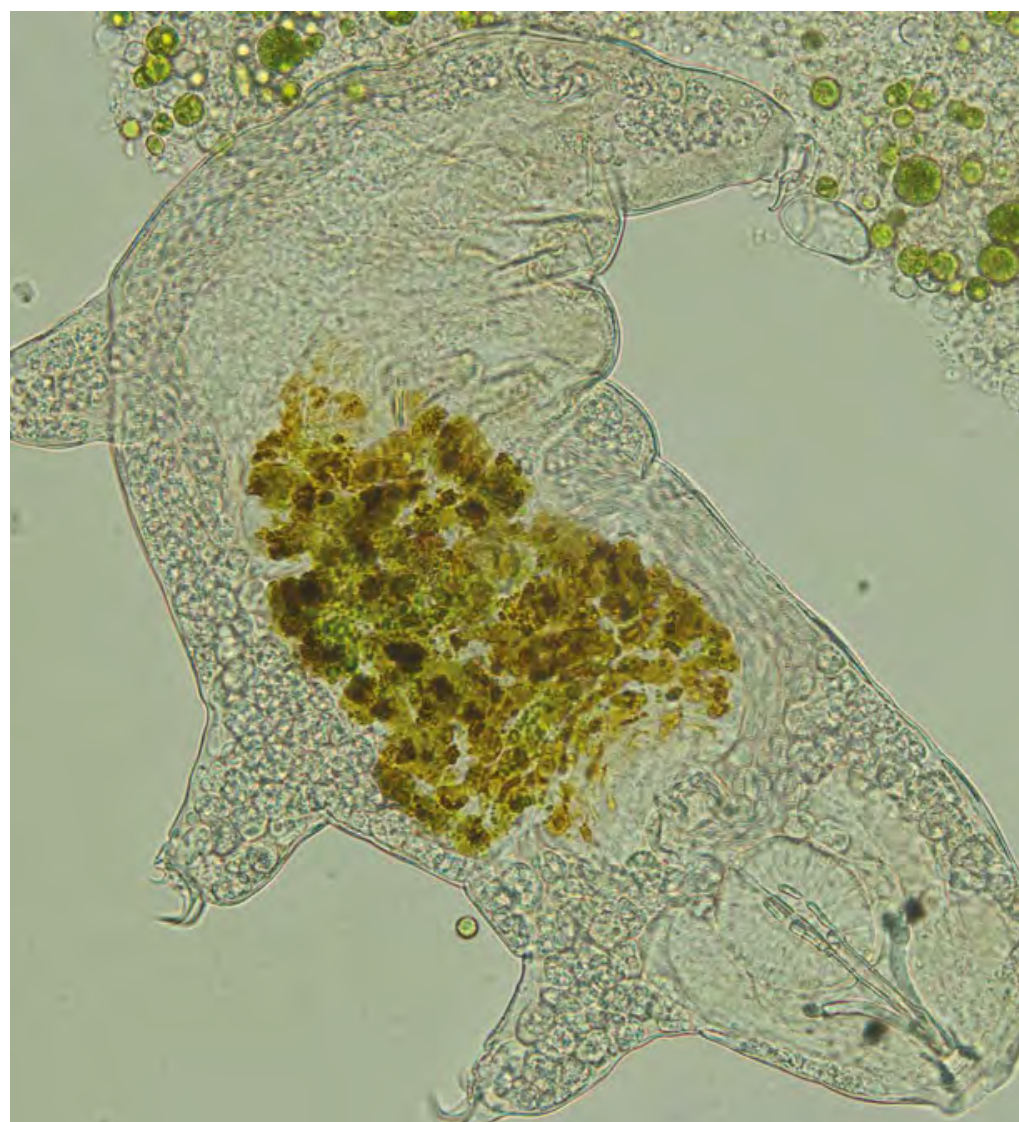

Roślinożerny niesporczak Dactylobiotus dispar podczas żerowania / fot. dr hab. Izabela Poprawa, prof. UŚ 


\section{KAŻDY SUPERBOHATER MA SŁABE STRONY}

Prawdą jest, że niesporczaki doskonale znoszą ekstremalne warunki środowiskowe. Mogą przetrwać w temperaturze bliskiej zeru absolutnemu, czyli rzędu $-270^{\circ} \mathrm{C}$, jak również w temperaturze nawet $150^{\circ} \mathrm{C}$. Przeżyły podróż w kosmos. Choć preferują środowiska wilgotne, takie jak siedliska porośnięte mchami, możemy je spotkać zarówno w obszarach subpolarnych, jak i w pobliskiej piaskownicy czy w domowym ogródku. Czy da się je dostrzec gołym okiem? Największe okazy mają około 1,2 mm długości, te są jednak nieliczne. Zdecydowana większość gatunków niesporczaków ma około $0,5 \mathrm{~mm}$ długości.

Aktywne zwierzęta są narażone na wszystkie niebezpieczeństwa, które czyhają na inne organizmy na Ziemi, i tu nie ma wyjątków. Gdy dzieje się jednak coś niepokojącego, ciało niesporczaka przechodzi w stan kryptobiozy, czyli tzw. życia utajonego. W zależności od warunków może to być na przykład stan anhydrobiozy wywołanej zbyt małą ilością wody, kriobiozy - na skutek zbyt niskiej temperatury w środowisku, osmobiozy - na skutek zmiany zasolenia czy anoksybiozy pojawiającej się w wyniku niewystarczającej ilości tlenu.

W stanie anhydrobiozy procesy metaboliczne są na tak niskim poziomie, że praktycznie trudno je wykryć. Poza tym na skutek odwodnienia niesporczaki tworzą tzw. cystę-baryłkę. Ich ciało się obkurcza, zmniejsza się dzięki temu powierzchnia parowania, następuje usunięcie zbędnej wody z organizmu itd. Wszystko po to, aby przetrwać.

Nie wiemy, ile lat mogą przeżyć w tym stanie, dotychczasowe udokumentowane badania eksperymentalne wykazały, że co najmniej... trzydzieści. I tu dochodzimy do kolejnego paradoksu. Otóż niesporczaki są jak śpiące królewny. Badania wykazały, że ich organizmy nie starzeją się podczas trwającego stanu kryptobiozy. W praktyce oznacza to, że gdyby czterdziestoletni człowiek zapadł w taki stan i obudził się, powiedzmy, po stu latach, jego ciało nadal miałoby czterdzieści lat. Nic więc dziwnego, że naukowcy pragną poznać tajemnice niesporczaków.

Mimo iż nie są im straszne ekstremalne warunki, ostatnie badania wykazują, że niesporczakom mogą jednak zaszkodzić skutki... ocieplenia klimatu.

- W stanie kryptobiozy potrafią przetrwać w naprawdę wymagającym środowisku, ale mogą nie zdążyć się aklimatyzować do nieznacznie wyższych temperatur, które dziś coraz częściej są normą. Warto dodać, że badania te prowadzone były tylko na jednym gatunku niesporczaków, co oczywiście ma kluczowe znaczenie, ale wyniki powinny nam dać - i dają do myślenia - mówi biolożka.

\section{A CO BY BYŁO, GDYBY CZŁOWIEK ZYSKAt MOC NIESPORCZAKA?}

Niesporczaki po raz pierwszy zostały wysłane w przestrzeń kosmiczną w 2007 roku - w stanie anhydrobiozy. Większość z nich ocknęła się po powrocie, ale wśród czterech podróżujących gatunków największym superbohaterem okazał się Milnesium tardigradum. Ponownie nawodnione podjęły wszystkie podstawowe funkcje życiowe, w tym zaczęły się rozmnażać.

Niezwykłe zdolności tych małych organizmów rozpalają wyobraźnię ludzi. Co by było, gdybyśmy podróżowali na przykład na Marsa właśnie w stanie kryptobiozy, nie doświadczając negatywnych skutków długiej podróży, nie starzejąc się? Rozważania takie są dziś naturalnie fantazją, ale skoro istnieją na Ziemi organizmy, które mają określone możliwości, to znaczy, że pewne interesujące nas rozwiązania nie są naturze obce.

Oczywiście wciąż jeszcze daleka droga do odkrycia wszystkich tajemnic niesporczaków. Naukowcy poznali wprawdzie kilka białek i innych substancji odpowiedzialnych na przykład za ochronę DNA tych bezkręgowców przed uszkodzeniem w wyniku różnych ekstremalnych warunków czy wpływających na proces krystalizacji wody w ciele, co ma szczególne znaczenie w stanie kriobiozy, gdy woda, zmieniając stan skupienia, mogłaby rozerwać komórki ich drobnych ciał.

Badania pokazują, że bogactwo rozwiązań jest ogromne i właściwe danemu gatunkowi. Na dostosowanie - lepsze lub gorsze - do trudnych warunków ma wpływ także etap rozwoju, na którym znajduje się dany osobnik. Ten temat jest jednym z głównych zainteresowań naukowych prof. Izabeli Poprawy. Analizy prowadzone są we współpracy z zespołem naukowców z Uniwersytetu im. Adama Mickiewicza w Poznaniu. Badacze sprawdzają między innymi, na którym etapie rozwoju mamy do czynienia z największą przeżywalnością stanu anhydrobiozy określonych gatunków niesporczaków. Są to badania eksperymentalne. Najpierw suszy się wybrane okazy, potem się je nawadnia i obserwuje, zapisując wszystkie istotne parametry. $\mathrm{Na}$ kolejnym etapie planowane są badania genetyczne.

- Moje główne zainteresowania dotyczą także układu rozrodczego niesporczaków, co ma duże znaczenie w taksonomii i filogenezie - mówi prof. Izabela Poprawa.

Niesporczaki sytuują się pomiędzy stawonogami i pazurnicami. Dlatego badaczka szuka cech, dzięki którym będzie można lepiej zrozumieć ich klasyfikację. Naukowcom pomagają w tym nowoczesne narzędzia. Dzięki zaawansowanym technologiom można zrekonstruować trójwymiarowy obraz poszczególnych elementów układu rozrodczego, a następnie porównywać go do odtworzonych części organizmów dwóch interesujących nas siostrzanych typów. Te wyniki robią duże wrażenie w świecie nauki i przybliżają nas do lepszego poznania bezkręgowców. 